\title{
Educational Administration: Concept, Theory and Management
}

\author{
Sin Ngamprakhon ${ }^{1}$, Phramaha Sombat Dhanapanno², Phrakrubhattaradhammakhun ${ }^{3}$,Suddhipong \\ Srivichai $^{4}$ \\ ${ }^{1,2,3,4}$ Faculty of Education, Mahachulalongkornrajavidyalaya University \\ Email: ${ }^{1}$ sin.ngm@mcu.ac.th, ${ }^{2}$ chaibie2529@ hotmail.com, ${ }^{3}$ sombat.cha@mcu.ac.th, ${ }^{4}$ therapong.som@mcu.ac.th
}

\begin{abstract}
The objectives of this research were: 1) to study the concepts and theories of educational administration, 2) to study the model of educational management, and 3) to analyze the theoretical tendency and the educational management model in practice. The primary data were collected from the Tipitaka in Thai version of Mahachulalongkornrajavidyalaya University and Commentaries. The secondary data were collected from Buddhist documents, educational administration, and interviews with 10key informants. The collected data were analyzed by content analysis. The research results indicated that: 1) the concepts and theories concerning academic affairs, teaching and learning management and evaluation by information technology, personnel management are an important part to drive the organization into effectiveness by setting job channel and description, and personnel development in virtue and knowledge. The budget is a factor to make the organization achieve its goal. The institutional environment is to support the management and work performance effectively. Furthermore, the participation in educational administration is a key factor to push the operation according to policy and plan. 2) The educational management model based on the Ministry of Education consisted of 4 aspects; Academic management, Budget management, Personnel, and General administration with stability and relevant to the 20-Year National Strategy and Thailand 4.0, by development and empowerment of potential, opportunity, equality of people, and enhancing people's quality of life with eco-friendly system, and educational system and management development. 3) The analysis of theoretical trends and educational management models into practice in 4 aspects; academic affairs, budget, personnel, and general management in practice is to strengthen the stability and reconciliation relevant to modern administration system with innovation and social network by using the educational administration in the digital age integrated with Buddhist principles to become a professional administrator in the present situation.
\end{abstract}

Keywords

Educational Administration, Concept and Theory, Management.

Article Received: 10 August 2020, Revised: 25 October 2020, Accepted: 18 November 2020

\section{Introduction}

Education reform is an important way to change education to be good and qualified education. The key tool for Thai education reform is The National Education Act (No. 3), 2010. It is the first time that a national education policy has become an act. This is an important change in concept, structure and process with a commitment to raise the quality of Thai education and the quality of the Thai people as a whole [1]

Educational administration is essential to improving the quality of education in schools, institutions and nation. Management is an important thing that is absolutely necessary. It is an indication of the quality of the school in the field of educating students as a guideline for educational administration of administrators. To develop personnel in education and educational institutions to be efficient and effective which administration consistent with the concept of Phradharmakosajarn (Prayoon Dhammacitto) "Administration" is running a business successfully in collaboration with others, whether it is an enterprise for business benefits, government affairs or family affairs. They are under the same principle.

Therefore, management is concerned with all businesses by operating with others, having both external and internal elements, and Wiroj Sararatana said that "administration" corresponds to the English word "Administration", which means being a person administration of a particular organization or any one department. While Massie \& Douglas has mentioned that management is both artistic and professional, which are as follows [2]
1. In the case of art, it refers to the skills and knowledge that each person has developed in order to achieve a particular goal with the skills and knowledge developed. This may result from training or working with other people who have expertise or have developed their managerial skills, like a musician or painter who has been trained or learned from a skilled or highly skilled musician or painter.

2. In the case of science, it means the body of knowledge arising from the search for new knowledge with a scientific method. Information is collected by hypothesis and hypothesis testing, etc. As in the past century, new knowledge has been developed. Giving rise to many theories of administration which administrators can apply in combination with the "art" that has developed in each person. In simple terms, Art is a matter of action training for expertise. The science is about knowledge. Art is doing, and science is knowing what and how to do.

3. In the case of a profession, it arises from both the art and the science with the criteria showing the professionalism of having knowledge in that profession systematically by the person in that profession. It must always be intellectually developed, and needs attitudes for change. We are constantly searching for new ideas, focusing on serving others, requiring ethical principles that money is not a critical measure of professional success, and the professional standards established by professional associations are recognized, trained, and cultivate attitudes and values towards that profession.

The management of the organization is very necessary to require executives with knowledge of management including concepts, theories, and principles that promote 
effective management. If the management does not have knowledge of concepts, theories and Buddhist principles, the administration of the school, organization, and the nation's institution will not be successful, not being successful in good management. In Buddhism, there is a principle that can be applied to the principles of administration.

That is the principles of service (Sangahavatthu:). The Buddha has spoken of the 4 Sangahavatthu to monks. Sangahavatthu means principles of the care for each other, They are 1.Giving (Dàna), 2.Kindly speech(Piyavàcà), 3. Useful conduct (Atthacariyà), and 4. Participation and behaving oneself properly in all circumstances (Samànattatà). These are 4 things and giving, beloving, the existential in this world and Sangahavatthu in such dhamma as appropriate, like a wedge that holds a car that can run. Even if parents do not have good morals, children will not respect them. But parents are always benefactors for their children for a wise man praises and respect a great parents. [3]

Therefore, the researcher shows that educational administration: concepts, theories, and management model are important for corporate executives in applying the concepts, theories and good management model. It contains the principles of Buddhism and can be applied in management to make the organization more successful and progressive

\section{Research Objectives}

1. To study concepts of educational administration theory

2. To study a model of educational administration

3. To analyze theoretical trends and models of educational administration into practice

\section{Research Methods}

\section{Research Design}

The research model is qualitative. It is documentary study and collecting data from documents and evidence related to the theoretical concepts about education, research books

\section{Research Process}

The research Process as follows:

1. Study and collect information from documents and related evidence, books, meeting minutes, Buddhist principles and other documents based on the concept and theories about educational administration,

2..Study and research related scriptures and Buddhist books for integration with educational administration,

3. Study and analyze concepts, theories about educational administration and integrated Buddhist principles,

4. Summary of educational administration models with integrated principles of Buddhism, and

5. Interviewing, Informal Interview from a group of 10 academics and Buddhist experts and focus group discussion with 8 persons consisting of monks and laymen who have knowledge of educational administration.

\section{Data collection}

The researcher has collected information from the following documents:

1. Study from the related research papers in order to get information about educational administration: concepts, theories and models of management,

2.Study information from the qualitative research papers on Educational Administration: Concepts, Theories, and Management Models,

3. Field Study, the method of interviewing and group discussion were used to collect truthful information as much as possible, and

Data preparation follows the following steps;

1) Data preparation, questionnaire, interview and group discussion, recording by media,

2) Bring the recorded information to summarize in each issue and categorized to find answers according to the content of research,

3) data analysis

Researchers have taken information from interviews and group discussions and organize a recording of descriptive in order to use the data for analysis and create new knowledge. The analysis of the results of this study is based on theoretical analysis of Supang Chanthawanit,

4) Analytic induction, which is a method to summarize data according to sensible or visible phenomena, etc. and

5) Data analysis by analyzing documents in educational administration: concepts, theories and models of management in four areas: academic administration model, human resource management model, budget management model, and general management model.

5. Analyze data, documents in the Tripitaka and books on educational administration: concepts, theories and models of management.

1) Invite 8 experts in educational administration and Buddhism for group discussions,

2) An interview with 10 experts in educational administration and Buddhism

\section{Research Findings And Dicussions.}

The concept and theory of educational administration were as follows:

1) Theoretical trend of academic administration into practice

1.1 Planning of academic work, it is a plan about curriculum development and course implementation. Pre-management about teaching and learning tend to plan about academic work into practice by strengthening the stability of the main institutions and inducing royal wishes and royal currents in education, curriculum development, teaching subjects with historical and monarchical subjects, to develop teaching and learning processes for reconciliation, such as friend support 
activities and elevate English subjects to support Thailand 4.0

1.2 Organization of work related to teaching and learning to make teaching by doing well and can be practiced in educational institution. Therefore, there must be an instructional management. There is a trend towards teaching and learning operations into practice, learning innovation quality and standard, develop quality and production standards for teachers and educational personnel, and develop the qualifications of teachers and educational personnel.

1.3 Organizations of teaching and learning are a facility and promotion of curriculum and educational programs for efficiency and quality. There is a trend of teaching and learning management into practice, development of educational management to strengthen the stability of the national core institutions, democratic government with the King as head of state, enhance the quality and promote access to education in special development zones, and upgrade quality and promote access to education in special areas.

1.4 Measurement and evaluation process to be used as a tool for reviewing and analyzing academic results. In line with the current educational reforms that focus on measurement and evaluation with information technology systems, ICT reforms for education. Developing the internet system and high speed internet database system is in line with Chomkhae Pongcharoen's research on "Development of a creative and productive school management model in Thailand", which concluded that evaluation of feasibility and feasibility of experts on the subject of developing creative and productive school management models in Thailand. In the origin of the form, the layout elements are appropriate at a high level. (The average value was 4.00 and 3.83, respectively). The conditions and the use of the model were at a moderate level (Mean value of 3.50) for the feasibility of the creative and productive school management model in Thailand. According to expert assessment, it was found that the origin of the model and the composition of the format was appropriate at a high level. (The average was 3.67 and 3.80 , respectively). The conditions and the use of the model were at a moderate level. (Mean value is 3.20) [4]

2) Theoretical trends in academic administration into practice

Personnel management is an important part that drives the organization's efficiency by personnel management. Executives must focus on the personnel in the organization, namely,

2.1 The duties and responsibilities of personnel are clearly defined, that is, the operators know the roles, duties, responsibilities and performance goals, both quantitative and qualitative, to be expected from them. It is in line with the current education reform production and development of manpower to increase competitiveness. It is the production and development of people to meet the needs of the national development and carry out a major project including adjusting the competency assessment system that reflects the efficiency of learning management. Teaching and student quality development are important.
2.2 The human resource management process is clear and acknowledged by all personnel of the organization. It is in line with the current education reform. Teacher reform has undertaken many important projects. There is a clear trend in the personnel management process and teacher potential development, especially English for executive quality development.

2.3 Focus on work quality from personnel for the benefit of the people and government agencies that have a focus mainly on the social performance goals. In pursuit of this goal, the value of the remuneration that the state gives to workers is measured by the beneficial results of the target and it tends to focus on quality results from personnel to practice by organizing a teacher training course in connection with obtaining academic qualifications and obtaining a teaching professional license.

2.4 To emphasize the principle of virtue, consistency, no prejudice, unselfishness, emphasis on the principle of adherence to work, this principle takes knowledge, competence, self-behavior and performance as a measure of merit without feeling or personal knowledge determines in line with education reform management reform. The management system has been adjusted in several areas as follows: Development of educational management in the form of partnership school by integrating digital technology for education to be used for mutual benefit in both infrastructure and network systems, information system for education, media and knowledge.

3) Theoretical trends in budget management into practice. Budget is a part of promoting organizational management to be efficient and successful in all aspects of the organization's management. Budget management is something that executives have to pay attention to and prevent mistakes because it is a matter of the survival of the organization as follows;

3.1 Preparation of budget; preparation in both income budget and expenditure budget in budget preparation process. There is a trend in preparing the budget for practice, including improving the educational administration structure and increasing the efficiency of school management.

3.2 Approval of budget consideration that the agency proposed by the authorized person to approve the budget. He has the power to analyze, cut and modify the budget but it must be within the proposed budget limit and having tendency to prepare budget into action.

4) Budget expenditure control management in accordance with budget approved work plans and projects in order to prevent leakage by controlling disbursement. The audit is made according to the regulations set by the organization. There is a trend of budget management into action.

5) Theoretical trends of general administration into practice as follows;

\subsection{Environment}

The institutional environment plays an important role in supporting the efficient and effective teaching and learning and operation of the educational institution by creating a good atmosphere or an open atmosphere. It is an atmosphere of cooperation and mutual respect, i.e. trust and considerate, to have satisfaction in work and unobstructed. Everyone has 
a sense of belonging and has good morale at work. This type of atmosphere is classified as desirable atmosphere.

There is a tendency to favorable or open atmospheres to practice as follows; organizing physical environments, such as physical environments and school grounds, school buildings, buildings, classrooms, assembly rooms, equipment and materials. Academic environment includes teaching and learning atmosphere both inside and outside the classroom as well as providing services.

5.2 Participation in educational administration

Participation in educational administration is an opportunity for those who are involved to take part in education management in order to develop learners to be effective with tangible results. It is consistent with the research of Duangduen Phanthumnawin on "The finding of important hypotheses of leadership [5] satisfaction according to Fieldale theory from concrete studies in Thailand". It was found that "Thailand's leadership will be satisfied depending on the popularity of the majority even though those leaders would not do much benefit for them. One interesting thing in Thailand is that a leader who is popular with most people is a quality leader. The good qualities of a leader include important psychological and behavioral attributes. But Fieldler's theory will only support Thai leaders with good psychological personality. "

\subsection{Educational management model}

Ministry of Education has defined the scope of the administration of the school into 4 groups, namely academic administration, budget management, personnel management and general administration. In accordance with the current Minister of Education, it provided a policy for operating guidelines. And important projects of the Ministry of Education are based on the National Strategy Framework; To build stability, Develop manpower and build competitiveness, Develop and empower people, Curriculum development, Teaching and learning process, Measuring and evaluating the production results, developing teachers, faculty and educational personnel, creating opportunities for equality and reducing educational disparities, Create opportunities and equality in education by enhancing educational quality, Increase educational opportunities through digital technology, organize a system for admission to university (Admission), to enhance the quality of life of citizens environmentally friendly, Curriculum development, Teaching and learning process, develop systems and management, Management system development on the law to improve the personnel management system of government teachers and educational personnel, and Establishment of the Ministry of Higher Education. That is clearly concrete in area policy driving to manage large schools and small schools.[6]

4.3 Analyze theoretical trends and educational administration models into practice

1) Trends in academic administration towards implementation of the Buddhist Integration Principle

By strengthening the stability of the main institutions by inducing royal wishes and royal currents in education curriculum development, teaching subjects with historical and monarchical subjects, Develop teaching and learning processes for reconciliation, such as friend support activities for upgrading English language courses to support Thailand
4.0 by integrating Buddhadhamma principles together with practice guidelines, namely wisdom resulting from study, wisdom resulting from reflections, wisdom resulting from mental development to integrate academic administration, namely Wisdom refers to knowledge and understanding that arises from listening, reading, speaking, learning, and creating wisdom. That affects learning, including external factors, including manuals, textbooks, places, environment, knowledge, etc. Wisdom refers to cognition that causes intelligence from thinking for innovative approaches or activities that promote or create the rise of a process in analyzing and synthesizing information rationally and critically. wisdom refers to knowledge and understanding that produces wisdom from practice. Practice is activity that allows learners to perform and gain knowledge and understanding by oneself.[7]

2) Trends in human resource management to the practice of the Buddhist integration

To develop a production system and develop teacher quality and have a spirit of being a teacher, it focuses on teachers to have qualifications in accordance with the subjects taught and bring appropriate information technology and tools to teaching as a tool to assist teachers or for self-learning such as distance learning, E-learning system, etc., as well as revising the performance assessment system that reflects the efficiency of learning management. Teaching and student quality development are important. Organizing a teacher production project for local development is given to the Office of the Basic Education Commission and the Office of the Vocational Education. Commission is the main agency conducting teacher recruiting (production, recruiting model appointment follow-up with development) and providing opportunities for smart people to become teachers.

In the personnel management in the $21 \mathrm{st}$ century, administrators have to formulate policies, annual human resource development plan and follow the plan clearly, and apply it with the 4 principles of influence which is the ladder of success in all operations; 1) Chanda: pleasure with the management, co-thinking, joint planning, 2) Viriya: Perseverance does not give up in the undertaking of such activities by practicing tirelessly, 3) Citta: cares not to be engaged in that matter by working together to decide to follow the plan correctly and appropriately, and 4) Vimamsa: must continue to work. The four successful ladders mentioned herein are the most important because they are joint consideration, follow up on the work done and solving the problems that arise during the work. Together to think, develop, improve, and work better in order to obtain benefit from the management for success and sustainable development.[8]

3) Trend of budget management towards implementation of the integrated Buddhist principles

Money management involves a high level of risk, and the management must consist of understand and comply with the rules and regulations. The management must have budget planning, set productivity and cost calculations, organize a procurement system, financial management and budget control, financial reports and performance asset management and internal audit. Schools must have a department responsible for internal auditing. There is 
freedom to operate, have clear duties and responsibilities on financial audits and results by applying the principles of the use of property in Buddhism. The principles gave the concept of the use of property and earned money. In Buddhism, the treasures obtained are allocated into 5 parts: 1. Raising oneself, raising mother, father, children, and wife to be happy, 2. Nourish friends and the associates to be happy, 3. Use to protect and maintain welfare to make oneself stable and safe from danger, and 4. To make sacrifices, meaning sacrifice to nurture and worship 5 things.

4) Trends of general administration to the implementation of the Buddhist Integration Principle

To provide physical environment, such as school area, school building, assembly building, classroom, assembly room, equipment and materials. Academic environment includes teaching and learning environment, both inside and outside the classroom as well as providing services to promote various academic and supporting by setting up an environment in Buddhism. It helps to support the practice of meditation to be effective. It helps concentrate on staying firm and promoting learning in the organization, such as avasa sappaya means a suitable abode, for example, it is not crowded, orbiting, Sappaya means suitable of the area, not too close, not too far. Bhassa sappaya means a suitable speech, like being with the body support for health apparently. Utu sappaya refers to the suitable climate and the environment that are suitable, such as not too cold, not too hot, etc. Iriyapatha sappaya means the suitable posture.[9]

Participation in educational administration into practice include curriculum development, teaching and learning process measurement and evaluation, production, development of teachers, faculty and educational personnel strategy for production and development of manpower. It includes research that is consistent with the needs of national development strategies to expand access to educational services and life-long learning. The administration has been integrated with the principles of Buddhism, called Saraniyadhamma. Dhamma is the location of remembrance of each other. It is considered that the Dhamma is the power to create harmony. There are 6 principles: to be amiable in deed, to be amiable in words, to be amiable in thought, to share lawful gains, to keep without blemish the rules of conduct, and to be endowed with right views. [10]

\section{Recommendations}

\section{Recommendations for Practices}

Educational Administration: Concepts, Theories, and Models of Management by Academic Administration, According to the national education plan by strengthening the stability of the main institutions inducing royal wishes and royal currents in education curriculum development, teaching subjects with historical and monarchical subjects, develop teaching and learning processes for reconciliation, such as friend support activities, enhance the level of English language to support Thailand 4.0, support people of all ages, knowledge and development of quality of life appropriately.

Personnel management according to the power rate plan; Develop a production system and develop quality teachers and have a spirit of teacherhood, a focus on teachers to have qualifications in accordance with the subjects taught, bring appropriate information technology and tools to teaching and as a tool to assist teachers or for self-learning such as distance learning, E-learning system, etc., as well as revising the performance assessment system that reflects the efficiency of learning management, and importance of teaching and student quality development.

In budget management, transparency, accountability, improvement of educational administration structure, to increase the efficiency of school management, promote the participation of all sectors in the provision of education, and improve the laws about the financial system for education that affects the quality and efficiency of educational administration. Budget is planned, productivity is set up and cost calculation is done, and procurement system is organized. In financial management and budget control, there are financial reports and performance asset management and internal audit. Once the budget has been obtained, the budget is allocated correctly, transparently and can be examined; offering monks.

The general administration with the community tends to participate in educational administration into practice, including curriculum development, teaching and learning process, measurement and evaluation, production, development of teachers, faculty and educational personnel strategy for production and development of manpower including research. That is consistent with the needs of national development encouraging to follow the Saraniya Dhamma principles, including creating unity, to be helpful and supportive, do not bully and hurt others, have good, polite, and sweet words, do not think malicious and vengeful, sharing, not taking advantage of each other, and together to think, solve problems and gain mutual benefits.

\section{Recommendations for Further Research}

1. Study on the integration of educational administration with Buddhist principles in their application in school administration.

2. A study of Buddhist methods of administration into the practice of educational institutions in the era of Thailand 4.0.

\section{Conclusion}

It can be concluded that academic administration according to the national education plan by strengthening the stability of the main institutions induce royal wishes and royal currents in education curriculum development teaching subjects with historical and monarchy subjects develop teaching and learning processes for harmony and harmony. Personnel management according to the power rate plan develop a production system and develop quality teachers and have a spirit of being a teacher. They should be focus on teachers to have qualifications in accordance with the subjects taught, bring appropriate information technology and tools to teach and teach as a tool to assist teachers or for 
self-learning, budget management, transparency, accountability, improvement of educational administration structure. The general administration with the community tends to participate in the administration of education into action to help and support others. Do not bully and hurt others, have good words, polite, sweet, do not think malicious and vengeful, sharing, not taking advantage of each other and together to think, solve problems and gain mutual benefits.

\section{References}

[1] Ministry of Education, Ministry of Education and Driving Educational Reform, Bangkok: Printing House, Transportation Organization, 1999.

[2] WirojSararatana,

Educational Administration, Principles, Theories, Functions, Issues and Analysis, Bangkok: Thiphayawisut Publishing House, 2003.

[3] Supang Chanthawanit, Qualitative Research Methods, Chulalongkorn College Book Center, Bangkok: 1997.

[4] ChomkaePongcharoen, "Development of a Creative and Productivity School Management Model in Thailand", a complete research report, Dhurakij Pundit University, 2011.

[5] DuangduenPhanthumnawin, "Political Leadership", Journal of Development Administration 39, December 4, 1999.

[6] BamrungSukporn, "The Study of the Monastic Education Management", Research Report, Faculty of Journalism and Mass Communication: Thammasat University, 2001.

[7] PhraDharmakosajarn

(PrayoonDhammajitto), manages a Buddhist organization to elect Dharma to meet the crisis, Bangkok: Prachachat Business Newspaper, 2010

[8] Pisamai Civil Nukroh and Faculty, "Sangha Education and Educational Reform under the National Education Act B.E.

[9] SupalakSethaphanich, "Development of a Management System Focusing on Excellence of Private Educational
Institutions", a complete research report, Chulalongkorn University, 2007.

[10] Office of the National Education Commission, "State of Education Management of the Thai Sangha", Complete Research Report, Bangkok: Office of the National Education Commission, 1983. 